\title{
ARSENIC CONTENT OF RAW AND COOKED RICE AND VEGETABLES GROWN IN MATLAB AREA OF CHANDPUR DISTRICT OF BANGLADESH
}

\author{
Zinat Mahal, Hasan M. Zahid*, M.A. Wahed ${ }^{1}$ And Harun K.M. Yusuf \\ Department of Biochemistry and Molecular Biology, \\ University of Dhaka, Dhaka-1000, Bangladesh
}

Key words: Arsenic, Raw and cooked rice, Vegetables

Samples of rice and some vegetables (Amaranth leaves, arum stem, green banana, amaranth stick, brinjal, potato) were collected from Uttamdi and Naojam villages of Matlab area of Chandpur district, Bangladesh and were analyzed for arsenic (As) content by Hydride Generation Atomic Absorption Spectrophotometry (HG-AAS). Both raw and cooked samples of the food items were studied. The As concentration in raw rice was $239.1 \pm 13.68 \mu \mathrm{g} / \mathrm{Kg}$, whereas the value was $56.34 \pm$ $22.95 \mu \mathrm{g} / \mathrm{Kg}$ in cooked rice. The reduction in As content was $76.4 \%$, presumably the loss of As was due to discarding of the bran after cooking the rice. In contrast, the mean As concentrations in raw and cooked amaranth were $22.8 \pm 3.76$ and $145.6 \pm$ $141.39 \mathrm{\mu g} / \mathrm{Kg}$, in raw and cooked arum were $7.03 \pm 0.07$ and $110.33 \pm 100.4 \mathrm{\mu g} / \mathrm{Kg}$ respectively. There were thus remarkable increases of As concentrations in cooked vegetables compared to raw. The higher concentration of cooked vegetables was presumably due to cooking with As contaminated tube-well water containing a high concentration of As. The results of this study showed the high potential for chronic exposure to As contamination of the villagers consuming these locally grown foodstuff.

Arsenic (As) pollution of ground water has been recognized as an acute environmental problem in Bangladesh. Groundwater is the primary source of drinking water for the inhabitants of rural Bangladesh, with approximately $95 \%$ of the population are consuming water obtained from bore whole wells (tube-wells). Conservative estimates indicate that in Bangladesh, about 30 million people are exposed to the risk of being affected by arsenic contaminated water and about 220,000 people are suffering from arsenic related diseases ranging from melanosis to skin cancer. ${ }^{(1)}$ The presence of arsenic above the limit of safe drinking water (50 $\mu \mathrm{g} / \mathrm{l}^{(2)}$ was first detected in ground water of the Bengal Delta Plain (BDP) aquifers in Bangladesh in 1993.(3) The main route of As exposure for the general population is via drinking water. Most groundwater used for irrigation in Bangladesh are contaminated with arsenic. ${ }^{(4)}$ Arsenic enters into the human body through drinking of

*Corresponding author. <zahid_bmb@yahoo.com>. 1Department of Biochemistry and Molecular Biology, University of Dhaka, Dhaka-1000, Bangladesh. 
groundwater and ingestion of contaminated foods obtained from groundwater irrigated agricultural fields and it goes on accumulating in the body. The purpose of the present study was to estimate the As content of the staple food rice and some vegetables in both raw and cooked form grown in an As-prone area of Bangladesh, namely Matlab under the district of Chandpur and to see the changes that occur in these foodstuffs due to cooking. Rice and vegetables were chosen for our study because it is the main diet of the rural people.

Samples of rice and vegetables were collected from Uttamdi and Naojam villages in Matlab, Bangladesh. The vegetables included amaranth, arum stem, green banana, amaranth stick, eggplant and potato. About $1000 \mathrm{~g}$ of the edible part of each sample were collected from various agricultural small holdings into polythene bags using vinyl gloves. The samples were transported to the laboratory in suitable conservation conditions and washed with distilled water to remove soil. Some of these samples were cooked in accordance with the cooking customs of the population. Collected samples were frozen at $-20^{\circ} \mathrm{C}$ until analysis. Samples were then digested with nitric acid and perchloric acid before analysis with the hydride generation atomic absorption spectrophotometer.

Twenty per cent loss of crop (cereal) production due to high concentration (20 ppm) in arsenic in plant body was reported by Davies et al. ${ }^{(5)}$ Like other heavy metals arsenic is toxic to plant and its discharge into the environment must be carefully controlled and minimized. The As concentrations $(\mu \mathrm{g} / \mathrm{kg})$ in raw rice, amaranth, arum, and spinach were $239.1 \pm 13.68,22.8 \pm 3.76,7.03 \pm 0.1 \mu \mathrm{gg} / \mathrm{Kg}$ and that of cooked items were $56.4 \pm 22.3,145.6 \pm 141.4,110.3 \pm 100.4 \mu \mathrm{g} / \mathrm{Kg}$, respectively (Table 1).

Table 1. Concentration of As in raw and cooked samples of rice, amaranth and arum.

\begin{tabular}{|c|c|c|c|c|c|}
\hline \multirow[t]{2}{*}{$\begin{array}{l}\text { No. of } \\
\text { samples }\end{array}$} & \multirow[t]{2}{*}{$\begin{array}{l}\text { Name of } \\
\text { samples }\end{array}$} & \multicolumn{2}{|c|}{$\begin{array}{c}\text { Concentration of As in the } \\
\text { samples }(\mu \mathrm{g} / \mathrm{Kg})\end{array}$} & \multirow[t]{2}{*}{$\begin{array}{l}\mathrm{p} \\
\text { values }\end{array}$} & \multirow{2}{*}{$\begin{array}{l}\text { Decision (as SPSS } \\
\text { programme, where } \\
\text { level of significance, } \\
\alpha=0.01 \text { ) }\end{array}$} \\
\hline & & $\begin{array}{c}\text { Raw } \\
(\text { Mean } \pm \text { Sd) }\end{array}$ & $\begin{array}{c}\text { Cooked } \\
(\text { Mean } \pm \text { Sd })\end{array}$ & & \\
\hline 6 & Rice & $239.1 \pm 13.68$ & $56.37 \pm 22.95$ & 0.0001 & $\mathrm{p}<\alpha$, significant \\
\hline 3 & Amaranth & $22.8 \pm 3.76$ & $145.6 \pm 141.39$ & 0.280 & $\mathrm{p}>\alpha$, insignificant \\
\hline 3 & Arum & $7.03 \pm 0.07$ & $110.33 \pm 100.33$ & 0.187 & $\mathrm{p}>\alpha$, insignificant \\
\hline
\end{tabular}

The lower concentration in cooked rice was presumably due to discarding of bran after cooking the rice, which is a usual practice in Bangladesh. It may also be due to dilution during boiling with pond water or the surface river water. The people of that area use surface water instead of tube-well water for cooking rice because tube-well 
water contains high amount of iron that induce changes in the color of cooked rice. But if the people cook sticky rice without discarding water and the source of water is tube-well, then the As concentration may be higher in cooked rice than in raw. Statistical analysis represented a significant difference in the raw and cooked rice in terms of As concentration ( $p<0.01$ ). Matlab is long known as an arsenic endemic area; the tube-well water in this region contains high concentration of As (200 - 300 $\mu \mathrm{g} / \mathrm{l}^{(6)}$ that penetrates into the foodstuffs causing a great impact on health and nutrition of the people.

With a factor 6.4, the increased concentration of As for the cooked amaranth samples was due to cooking with As-contaminated tube-well water that was about to $539 \%$ i.e. arsenic entered into amaranth through water by 539\%. The addition of water used in cooking from the different sources may be responsible for this. Similarly, the As concentration in raw arum samples was the highest value compared with the cooking effect of another samples. Likewise, the average concentration of As in spinach samples was found about three times higher in cooked compared to raw samples (data not shown).

However, an insignificant result, as a statistical analysis, $p>0.01$, was observed in case of the change of As concentration in raw and cooked arum and amaranth. Some non-leafy vegetables like potato, green banana, corolla, data and brinjal were also analyzed, in raw form. The highest concentration of As was found in the brinjal $(7 \mu \mathrm{g} / \mathrm{l})$ and the lowest concentration was found in data, $1.28 \mu \mathrm{g} / \mathrm{Kg}$. The other values were: potato, $5.4 \mu \mathrm{g} / \mathrm{Kg}$; green banana, $5.35 \mu \mathrm{gg} / \mathrm{Kg}$; and corolla, $3.12 \mu \mathrm{gg} / \mathrm{Kg}$. This study suggests that leafy vegetables accumulate more arsenic than non-leafy vegetables.

Exposure of the food chain to As is not only caused by groundwater irrigation system, the cooking process is also responsible for this. Thus, As exposure can be reduced in a large scale if the people are customized to use surface water in all cooking processes. Quantitative determination of other toxic metals is also required to observe their contribution to the toxicity of As. The burning question now is the mitigation of As from the food chain, which is necessary and can be adopted by using different types of methods and by changing the social behaviors of the communities. For that purpose public awareness must be raised through the social workers by giving them suitable messages.

\section{References}

1. Rahman MM, D Mukherjee, MK Sengupta, UK Chowdhury, D Lodh, CR Chanda, S Roy, M Selim, Q Qumruzzaman, AH Milton, SM Shahidullah, MT Rahman and D Chakraborty 2002. Effectiveness and reliability of arsenic field-testing kits: are the million dollar screening projects effective or not? Env. Sci. Technol. 36: 5385-5394. 
2. WHO 2001. Arsenic in drinking water: Fact Sheet 210. Geneva. http://www.who.int/ mediacentre/factsheets/fs210/en/print.html (Accessed on March 9, 2004).

3. Ahmed KM, P Bhattachararya, MA Hasan, SH Akther, SMM Alam, MA Bhuyian, MB Imam, AA Khan and O Sracek 2004. Arsenic enrichment in groundwater of the alluvial aquifers in Bangladesh: An overview. Appl. Geochem. 19(2): 181-200.

4. Khan AW and SKA Ahmad 1997. Arsenic in drinking water: health effects and management. A training manual. Department of Occupational and Public Health. National Institute of Preventive and Social Medicine (NIPSOM), Dhaka.

5. Davies J and C Exley 1992. Hydrochemical character of the main aquifer units of central and northeastern Bangladesh and possible toxicity of groundwater to fish and humans. BGS Technical Report WD/92/43R and Supplement WD/92/44R, 1992.

6. Rahman M, M Vahter, MA Wahed, N Sohel, M Yunus, PK Streatfield, SE Arifeen, A Bhuiya, K Zaman, AMR Chowdhury, EC Ekstrom and LA Persson 2006. Prevalence of arsenic exposure and skin lesions. A population based survey in Matlab, Bangladesh. J. Epidemiol. Community Health 60(3): 242-248.

(Manuscript received on 11 May, 2009; revised on 18 July, 2009) 